\title{
Identifikasi Lapisan Lapuk Bawah Permukaan Menggunakan Seismik Refraksi di Desa Lengkeka Kecamatan Lore Barat Kabupaten Poso
}

\section{Identification Of Subsurface Decay Layer Using Refraction Seismic In Lengkeka Village West Lore Subdistrict Of Poso District}

\author{
Vicho Yugho Artono*), Rustan Efendi, Sandra \\ Jurusan Fisika, Fakultas MIPA, Universitas Tadulako
}

\begin{abstract}
The research on the identification of subsurface decay layer using refraction seismic has been done in Lengkeka Village, Lore Barat Sub-district, Poso District. The purpose of this research is to know the response of refractive seismic velocity on the subsurface layer and the thickness of the weathered layer by using the time delay method which is part of the refraction seismic method. This study was conducted on 4 different trajectories using 24 geophones on each track. In the paths $1,2,3$ and 4, the mean speed of the wave propagation are $1,177-2,388 \mathrm{~m} / \mathrm{s}, 690-890 \mathrm{~m} / \mathrm{s}, 1,550-2,220 \mathrm{~m} / \mathrm{s}$ and $1,396-2,075 \mathrm{~m} / \mathrm{s}$, respectively. Determination of rock structure is classified with wave velocity $\mathrm{P}$ on various sedimentary rocks as well as looking at geological condition of research area. The subsurface structure of each path has 3 constituent rocks, wherein the subsurface layer is dominated by alluvium rock, saturated sand, clay, layered or unsaturated sediments, and saturated pebbles. Based on the type of rock layer, then this area is suspected to experience weathering under the surface.
\end{abstract}

Keywords: Refraction seismic, Time delay method, Weathered layer.

\begin{abstract}
ABSTRAK
Penelitian tentang identifikasi lapisan lapuk bawah permukaan menggunakan seismik refraksi telah dilakukan di Desa Lengkeka Kecamatan Lore Barat Kabupaten Poso. Tujuan penelitian ini adalah untuk mengetahui respon kecepatan gelombang seismik refraksi pada lapisan bawah permukaan dan ketebalan lapisan lapuk dengan menggunakan metode waktu tunda yang merupakan bagian dari metode seismik refraksi. Penelitian ini dilakukan pada 4 lintasan yang berbeda dengan menggunakan 24 buah geophone pada setiap lintasan. Pada lintasan 1,2,3 dan 4 diperoleh kecepatan rata-rata perambatan gelombang secara berturut-turut $1.177-2.388 \mathrm{~m} / \mathrm{s}, 690-890 \mathrm{~m} / \mathrm{s}, 1.550-2.220 \mathrm{~m} / \mathrm{s}$ dan $1.396-2.075 \mathrm{~m} / \mathrm{s}$. Penentuan struktur batuan diklasifikasikan dengan kecepatan gelombang P pada berbagai batuan sedimen serta melihat kondisi geologi wilayah penelitian. Struktur lapisan bawah permukaanpada setiap lintasan memiliki 3 batuan penyusun, dimana lapisan pada bawah permukaannya didominasi oleh batuan alluvium, pasir tersaturasi, tanah liat, lapuk berlapis atau sedimen yang tidak terkonsolidasi, dan kerikil tersaturasi. Berdasarkan jenis lapisan batuan tersebut, maka daerah ini diduga mengalami pelapukan pada bawah permukannya.
\end{abstract}

Kata Kunci : Lapisan lapuk, Metode waktu tunda, Seismik refraksi. 


\section{LATAR BELAKANG}

Desa Lengkeka Kecamatan Lore Barat Kabupaten Poso merupakan wilayah yang berada di Lembah Bada. Informasi geologi di wilayah ini menyebutkan bahwa Lembah Bada terdiri atas Formasi Latimojong, Batuan Gunung Api Tineb'a, Granit Kambuno serta endapan danau berupa lempung (Simanjuntak, dkk, 1997). Wilayah ini merupakan daerah panasbumi, dimana terdapat sumber mata air panas. Daerah panasbumi atau medan panasbumi merupakan daerah di permukaan bumi dalam batas tertentu dimana terdapat energi panasbumi dalam suatu kondisi hidrologi batuan tertentu (Santoso, 2004). Lapisan batuan bawah permukaan bumi memiliki sifat fisis yang variatif. Salah satu sifat fisis yang terdapat di bawah permukaan adalah tingkat kekerasan batuan. Tingkat kekerasan batuan merupakan istilah geologi yang digunakan untuk menandakan kekompakan suatu batuan atau merupakan tekanan maksimum yang mampu ditahan oleh batuan untuk mempertahankan diri dari terjadinya rekahan (Rosid, 2008). Rekahan biasa terdapat pada suatu lapisan yang lapuk. Pengetahuan tentang lapisan lapuk bawah permukaan suatu wilayah sangat penting dikarenakan setiap kerusakan yang berupa pengikisan, rekahan, erosi atau gerak massa batuan selalu diawali oleh proses pelapukan. Penentuan perlapisan batuan bawah permukaan dapat dilakukan dengan menggunakan metode seismik refraksi, untuk mengetahui lapisan lapuk bawah permukaan di Desa Lengkeka Kecamatan Lore Barat Kabupaten Poso maka dilakukan penelitian dengan menggunakan metode seismik refraksi. Metode ini dilakukan dengan memancarkan gelombang ke bawah permukaan perlapisan batuan, respon tanah atau batuan direkam melalui geophone yang terpasang di atas permukaan tanah. Adapun tujuan yang ingin dicapai pada penelitian ini adalah untuk mengetahui respon kecepatan gelombang seismik refraksi pada lapisan bawah permukaan dan mengetahui ketebalan lapisan lapuk bawah permukaan.

Penelitian ini dilakukan di Desa Lengkeka Kecamatan Lore Barat Kabupaten Poso. Statigrafi dataran tinggi Bada Kabupaten Poso dapat dilihat pada Tabel 1 dan Peta Geologi lokasi penelitian dapat dilihat pada Gambar 1.

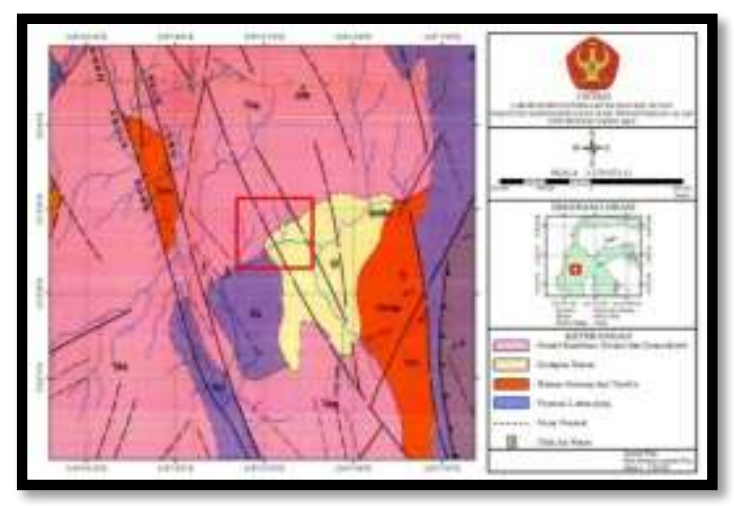

Gambar 1. Peta geologi lokasi penelitian (Simanjuntak, dkk, 1997). 
Tabel 1 Statigrafi dataran tinggi Bada Kabupaten Poso

\begin{tabular}{|c|c|c|c|}
\hline $\begin{array}{l}\text { Umur } \\
\text { Batuan }\end{array}$ & Formasi & $\begin{array}{l}\text { Deskrips } \\
\text { i Batuan }\end{array}$ & $\begin{array}{l}\text { Lingk } \\
\text { ungan }\end{array}$ \\
\hline $\begin{array}{c}\text { Kapur } \\
\text { - Eosen }\end{array}$ & $\begin{array}{c}\text { Formasi } \\
\text { Latimojo } \\
\text { ng }\end{array}$ & $\begin{array}{c}\text { Perseling } \\
\text { an } \\
\text { Batusaba } \\
\text { k, Filit, } \\
\text { Batupasi } \\
\text { r kuarsa, } \\
\text { Batugam } \\
\text { ping, } \\
\text { argilit, } \\
\text { Batulana } \\
\text { u, } \\
\text { konglom } \\
\text { erat, } \\
\text { rijang } \\
\text { dan } \\
\text { batuan } \\
\text { gunung } \\
\text { api }\end{array}$ & $\begin{array}{l}\text { Laut } \\
\text { Dala } \\
\mathrm{m}\end{array}$ \\
\hline $\begin{array}{c}\text { Miosen } \\
\text { Tengah } \\
- \\
\text { Miosen } \\
\text { Akhir }\end{array}$ & $\begin{array}{c}\text { Gunung } \\
\text { Api } \\
\text { Tineba }\end{array}$ & $\begin{array}{c}\text { Lava } \\
\text { andesit } \\
\text { horenble } \\
\text { nda, } \\
\text { Lava } \\
\text { basal, } \\
\text { Lava latit } \\
\text { kuarsa, } \\
\text { dan } \\
\text { breksi }\end{array}$ & $\begin{array}{c}\text { Gunu } \\
\text { ng api } \\
\text { bawah } \\
\text { laut }\end{array}$ \\
\hline Pliosen & $\begin{array}{c}\text { Granit } \\
\text { Kambun } \\
\text { o }\end{array}$ & $\begin{array}{c}\text { Granit } \\
\text { dan } \\
\text { Granodio } \\
\text { rit }\end{array}$ & $\begin{array}{l}\text { Pegun } \\
\text { ungan }\end{array}$ \\
\hline- & $\begin{array}{c}\text { endapan } \\
\text { danau } \\
\text { berupa } \\
\text { Lempun } \\
\text { g }\end{array}$ & $\begin{array}{c}\text { Lempun } \\
\text { g, lanau, } \\
\text { pasir dan } \\
\text { kerikil }\end{array}$ & - \\
\hline
\end{tabular}

Sumber: (Simanjuntak, dkk, 1997).

\section{BAHAN DAN METODE}

Penelitian ini dilakukan di Desa Lengkeka Kecamatan Lore Barat Kabupaten Poso. Pengukuran dilakukan pada tanggal 4 Maret 2017. Pengukuran dilakukan sebanyak 4 lintasan, untuk Lintasan 1 dengan posisi $01^{0} 51^{\prime} 58^{\prime \prime}$ LS dan $120^{\circ} 12^{\prime}$ 37' BT, Lintasan 2 dengan posisi $01^{0} 52$ ' 11 " LS dan $120^{\circ} 12$ ' $37^{\prime}$ " BT, Lintasan 3 dengan posisi $01^{0} 52^{\prime}$ 00" LS dan $120^{\circ} 12^{\prime} 37^{\prime}$ ' BT, dan Lintasan 4 dengan posisi $01^{0} 52$ ' $01^{\prime}$ ' LS dan $120^{\circ} 12^{\prime}$ 36" BT. Peralatan yang digunakan pada penelitian ini adalah satu set alat seismik refraksi, rollmeter (100 meter) untuk mengukur jarak antar geophone, global positioning system (GPS) untuk menentukan posisi geophone, software pickwin dan plotrefa untuk mengolah data hasil pengukuran, jam penunjuk waktu, peta geologi lembar poso, dan alat tulis menulis. Pengambilan data dari metode seismik refraksi adalah sebagai berikut : (1) Menentukan lintasan pengukuran, (2) Menentukan arah bentangan, Menentukan interval antar geophone, (4) Membuat bentangan dengan menancapakan tiap geophone ke tanah, (5) Menentukan lintang, bujur, dan elevasi setiap geophone dengan menggunakan GPS, (6) Menghubungkan kabel penghubung (Trigger, extension, conector), (7) Menjalankan program seismograf, (8) Memberi gangguan pada shoot point 5 kali berturut-turut di mulai dari titik 1,5 meter di depan geophone 1, titik geophone 6-7, titik geophone 12-13, titik geophone 18-19, dan titik 1,5 meter di 
belakang geophone 24. (9) Respon gelombang akan terekam secara otomatis pada seismograf dan data tersebut dapat diolah dengan menggunakan software Pickwin dan Plotrefa.

Pengolahan data sebagai berikut: (1) Data yang terekam, kemudian di download dari seismogram, kemudian diinput ke dalam program pickwin, (2) Memilih satu data yang paling bagus, (3) Selanjutnya dilakukan picking (menentukan waktu tempuh gelombang seismik yang pertama), (4) Memasukkan data elevasi tiap geophone dengan menggunakan program Notepad, (5) Memodelkan struktur bawah permukaan berdasarkan kecepatan batuan dengan menggunakan Plotrefa,

Melakukan inversi menginterpretasi hasil pemodelan menggunakan Time-term pada software Plotrefa, (7) Menetukan lapisan pertama, kedua dan ketiga berdasarkan kecepatan gelombang tiap lapisan, (8) Menentukan ketebalan tiap lapisan pada software Plotrefa, dan merata-ratakan ketebalannya dikarenakan bidang batas pada tiap lapisan tidak sejajar.

\section{HASIL}

Rekaman data gelombang seismik refraksi pada Lintasan 1 shoot point 1 ditunjukan pada Gambar 2 dan kurva travel time ditunjukan pada Gambar 3 sampai Gambar 6. Gambar tersebut memperlihatkan data rekaman penjalaran gelombang seismik refraksi di bawah permukaan yang terekam pada seismograf dan kurva travel time pada setiap lintasan. Pada Gambar 3 sampai Gambar 6 kurva travel timesetiap lintasan terlihat ada 5 grafik yang saling memotong dengan warna yang berbeda-beda. Grafik berwarna merah menunjukkan waktu tempuh gelombang seismik pada lapisan paling atas, grafik berwarna hijau menunjukkan waktu tempuh gelombang seismik pada lapisan kedua, sedangkan grafik berwarna biru menunjukkan waktu tempuh gelombang seismik pada lapisan paling bawah. Pada kurva travel time disetiap lintasan dapat dilihat jumlah lapisan batuan yang teridentifikasi, ini terlihat dari slope pada kurva travel time. Perbedaan slope penjalaran gelombang $\mathrm{P}$ pada kurva travel time mengindikasikan adanya perbedaan lapisan batuan.

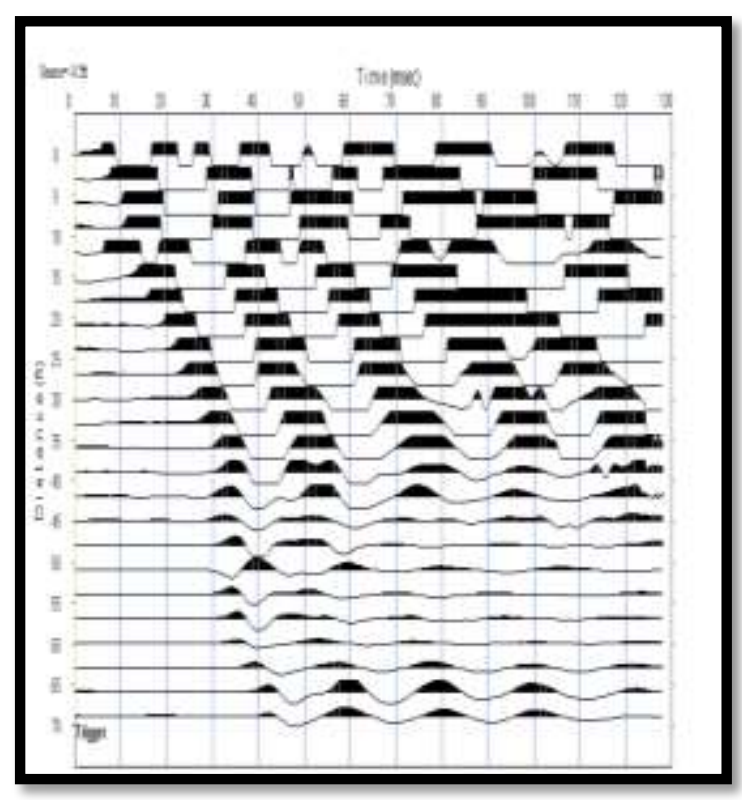

Gambar 2 Rekaman data pada shoot point 1, titik 1,5 m didepan geophone 1 


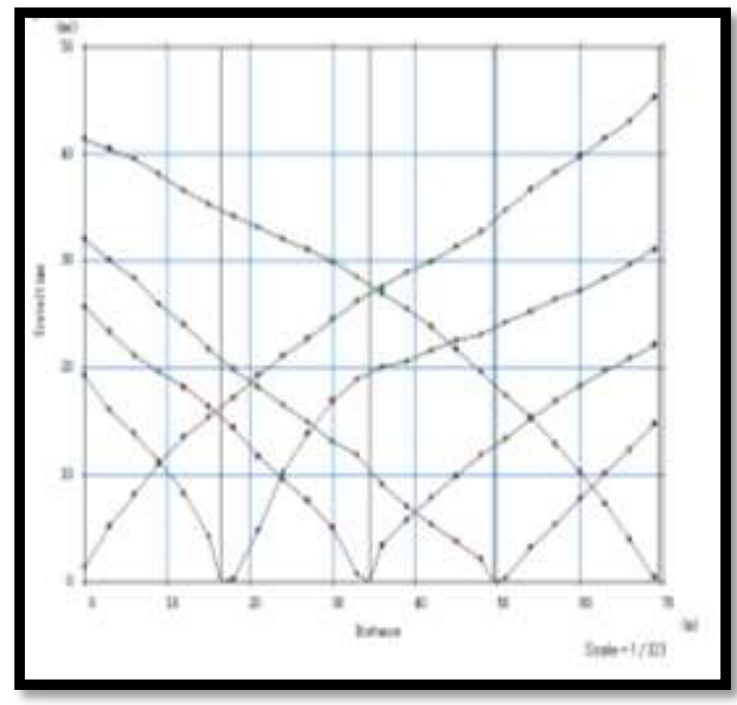

Gambar 3 Kurva travel time Lintasan 1

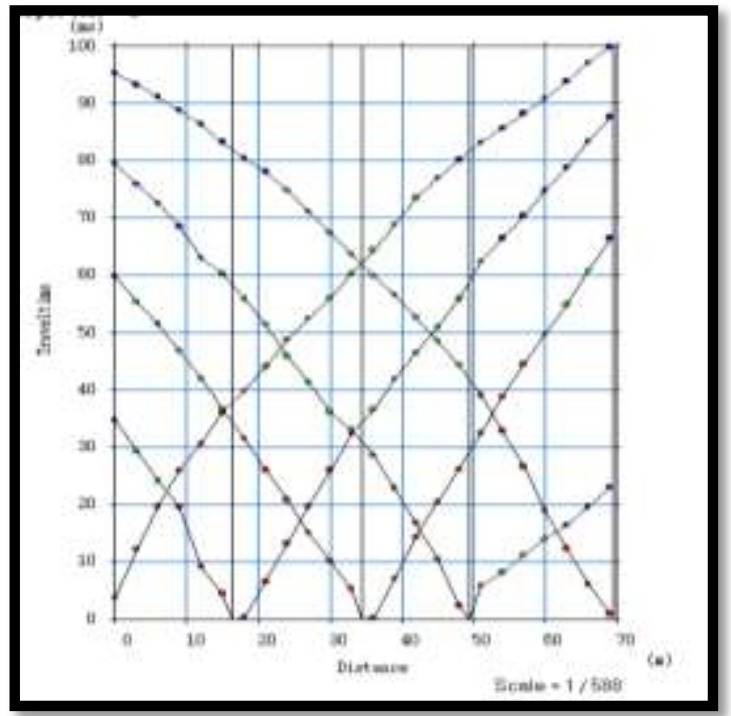

Gambar 4 Kurva Travel time Lintasan 2

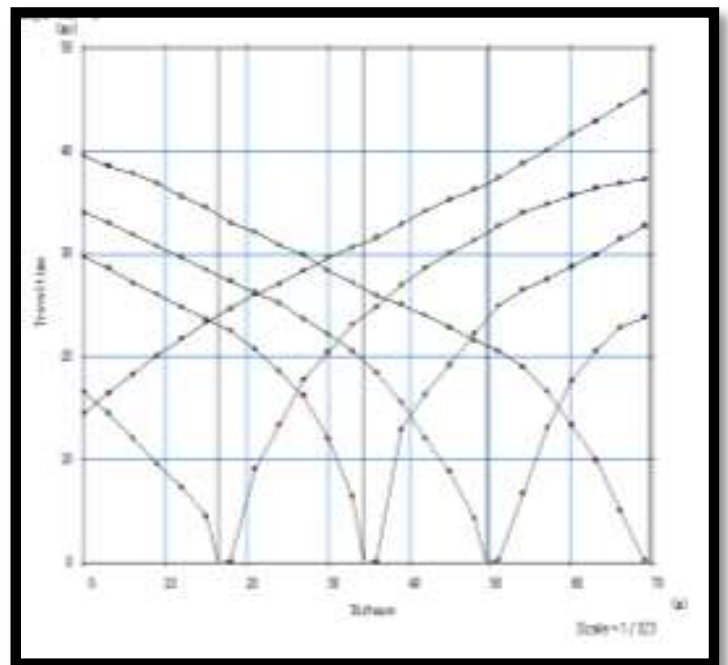

Gambar 5 Kurva travel time Lintasan 3

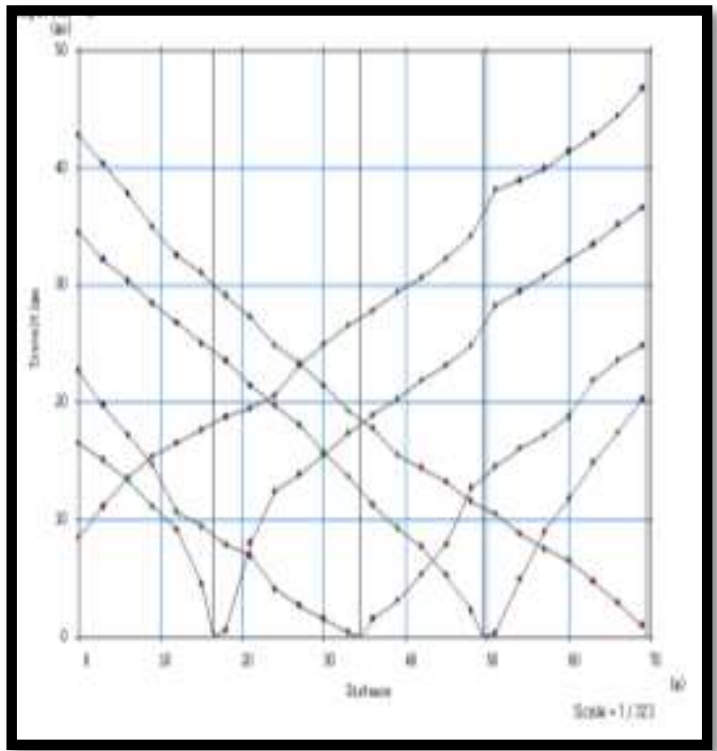

Gambar 6 Kurva travel time Lintasan 4

Pada pengambilan data dan pengolahan data digunakan metode waktu tunda. Metode waktu tunda menggunakan beberapa titik shoot pada tiap lintasan, sehingga metode ini efektif dan sangat kompleks untuk mendapatkan interpretasi lapisan bawah permukaan pada setiap lintasan. Dalam mengolah rekaman data gelombang seismik refraksi pada setiap lintasan, data yang terekam kemudian di download dari seismograf. Hasil rekaman data gelombang seismik refraksi pada titik 1,5 meter di depan geophone 1, titik geophone 6-7, titik geophone 12-13, titik geophone 18-19, dan titik 1,5 meter di belakang geophone 24 diinput ke dalam program Pickwin, selanjutnya dilakukan Picking pada rekaman data gelombang seismik. Picking bertujuan untuk menentukan waktu tiba gelombang pertama yang sampai pada setiap geophone. Setelah melakukan Picking

Identifikasi Lapisan Lapuk Bawah Permukaan Menggunakan Seismik Refraksi di Desa Lengkeka Kecamatan Lore Barat Kabupaten Poso (Vicho Yugho Artono dkk) 
maka akan diperoleh kurva travel time pada program Plotrefa. Kemudian memodelkan kecepatan gelombang seismik lapisan bawah permukaan berdasarkan data waktu tiba gelombang menggunakan program Plotrefa. Setelah melakukan pengolahan data pada kurva travel time selanjutnya memodelkan kecepatan lapisan bawah permukaan dengan program Plotrefa, maka hasil yang diperoleh setelah dilakukan pengolahan data seismik refraksi adalah model penampang kecepatan seismik 2-D yang dapat dilihat pada Gambar 7 sampai Gambar 10

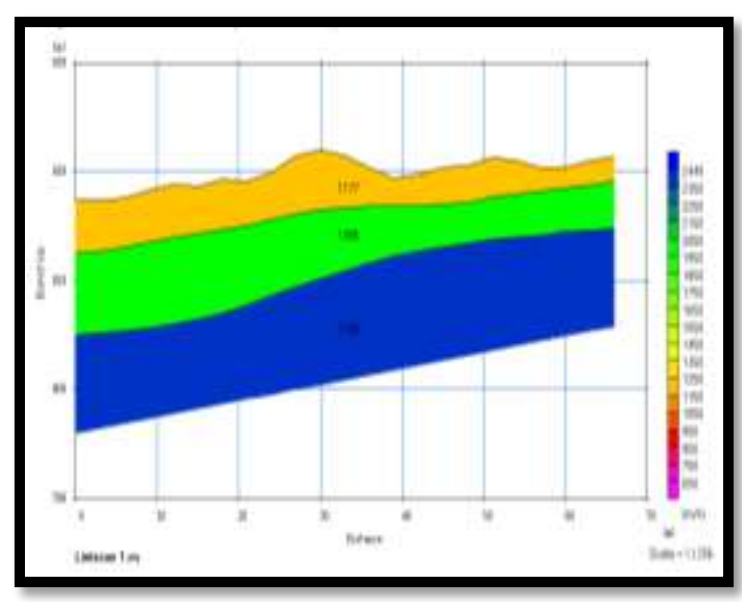

Gambar 7 Penampang kecepatan seismik 2-D Lintasan 1

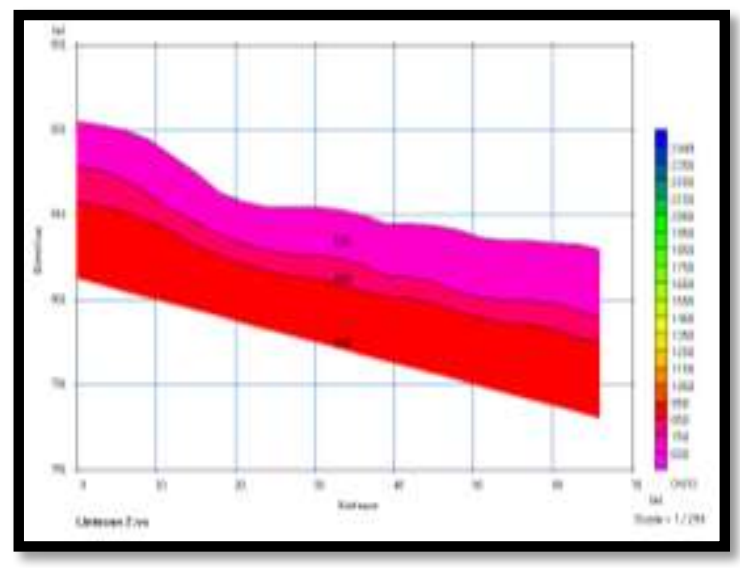

Gambar 8 Penampang kecepatan seismik 2-D Lintasan 2

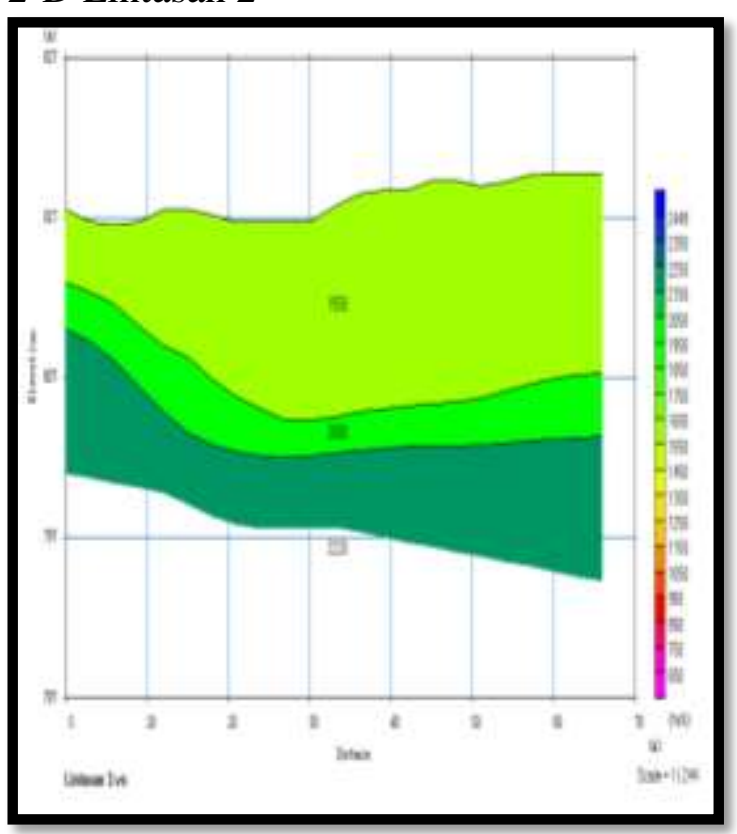

Gambar 9 Penampang kecepatan seismik 2-D Lintasan 3

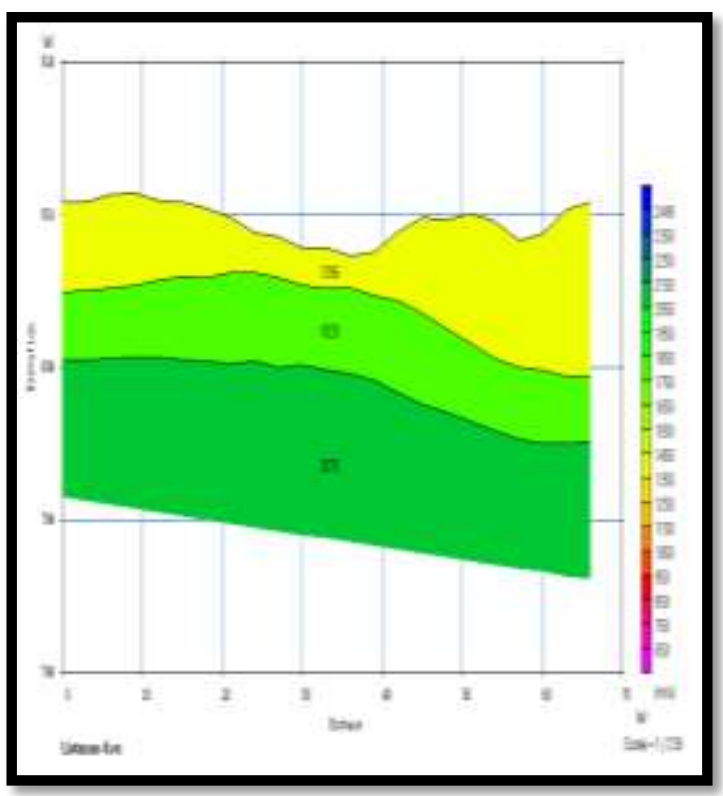

Gambar 10 Penampang kecepatan seismik 2-D Lintasan 4

Berdasarkan pemodelan dengan menggunkan software Plotrefa diperoleh model penampang seismik 2-D pada tiap lintasan. Gambar 7 merupakan model penampang kecepatan seismik 2-D pada Lintasan 1 dengan 3 lapisan penyusun.

\section{Identifikasi Lapisan Lapuk Bawah Permukaan Menggunakan Seismik Refraksi di Desa Lengkeka Kecamatan Lore Barat Kabupaten Poso (Vicho Yugho Artono dkk)}


Ketiga lapisan penyusun tersebut adalah lapisan pertama $\left(\mathrm{L}_{1}\right)$ dengan ketebalan sekitar 3,89 meter dengan kecepatan ratarata perambatan gelombang sekitar 1.177 $\mathrm{m} / \mathrm{s}$ diduga didominasi oleh alluvium (Burger, 1992). Lapisan kedua $\left(\mathrm{L}_{2}\right)$ dengan ketebalan sekitar 5,16 meter dengan kecepatan rata-rata perambatan gelombang sekitar $1.985 \mathrm{~m} / \mathrm{s}$ diduga didominasi oleh pasir tersaturasi (Burger, 1992). Lapisan ketiga $\left(\mathrm{L}_{3}\right)$ dengan ketebalan sekitar 9,57 meter dengan kecepatan rata-rata perambatan gelombang sekitar $2.388 \mathrm{~m} / \mathrm{s}$ diduga didominasi oleh tanah liat (Burger, 1992).

Pada model penampang kecepatan seismik 2-D yang terlihat pada Gambar 8, terdapat 3 lapisan penyusun. Dimana lapisan pertama dengan kecepatan rata-rata perambatan gelombang sekitar $690 \mathrm{~m} / \mathrm{s}$ dan ketebalan sekitar 6 meter diduga merupakan lapisan lapuk berlapis. Lapisan kedua dengan kecepatan rata-rata perambatan gelombang sekitar $800 \mathrm{~m} / \mathrm{s}$ dan ketebalan sekitar 2,9 meter diduga didominasi lapuk berlapis. Lapisan ketiga dengan kecepatan rata-rata perambatan gelombang sekitar $890 \mathrm{~m} / \mathrm{s}$ dan ketebalan sekitar 7,89 meter diduga didominasi oleh lapuk berlapis (Burger, 1992).

Dari hasil pengolahan data seismik refraksi pada Gambar 9 didapatkan model penampang kecepatan seismik 2-D pada Lintasan 3 dengan 3 lapisan penyusun.
Lapisan penyusun tersebut adalah lapisan pertama dengan ketebalan sekitar 10,4 meter dengan kecepatan rata-rata perambatan gelombang sekitar $1.550 \mathrm{~m} / \mathrm{s}$ diduga didominasi oleh alluvium. Lapisan kedua dengan ketebalan sekitar 3,23 meter dengan kecepatan rata-rata perambatan gelombang sekitar $2.000 \mathrm{~m} / \mathrm{s}$ diduga didominasi pasir tersaturasi. Lapisan ketiga dengan ketebalan sekitar 6,24 meter dengan kecepatan rata-rata perambatan gelombang sekitar $2.220 \mathrm{~m} / \mathrm{s}$ diduga didominasi oleh tanah liat (Burger,1992).

Pada Lintasan 4 model penampang kecepatan seismik 2-D pada Gambar 10 memiliki 3 lapisan penyusun yang didominasi oleh kerikil tersaturasi, dengan kecepatan rata-rata perambatan gelombang sekitar $1.396 \mathrm{~m} / \mathrm{s}$ dan ketebalan $6,82 \mathrm{~m}$ pada lapisan pertama. Lapisan kedua dengan kecepatan rata-rata perambatan gelombang sekitar $1.820 \mathrm{~m} / \mathrm{s}$ dan ketebalan sekitar 4,73 meter diduga didominasi alluvium. Lapisan ketiga dengan kecepatan rata-rata perambatan gelombang sekitar $2.075 \mathrm{~m} / \mathrm{s}$ dan ketebalan sekitar 9,66 meter diduga didominasi oleh pasir tersaturasi. (Burger, 1992).

\section{PEMBAHASAN}

Hasil pengolahan data menunjukkan bahwa lapisan bawah permukaan memiliki kecepatan gelombang dan ketebalan yang 
berbeda. Semakin besar kecepatan gelombang pada bawah permukaan maka semakin bertambah kedalamannya, sehingga akan semakin kompak pula batuan penyusunnya (Sismanto, 1999). Berdasarkan model penampang kecepatan gelombang seismik 2-D, diduga setiap lapisan di semua lintasan pada penelitian ini merupakan lapisan lapuk, dimana lapisan ke 1 pada setiap lintasan merupakan batuan sedimen yang tidak terkonsolidasi atau batuan yang mengalami pelapukan di atas permukaan kemudian terendapkan sehingga membuat lapisan ini akan sangat mudah mengalami pelapukan atau merekah.

Pada lapisan ke 2 dan 3 pada setiap lintasan diduga mengalami pelapukan batuan yang disebabkan oleh faktor temperatur yang tinggi di bawah permukaan. Hal dikarenakan lokasi penelitian ini merupakan daerah panasbumi dan lokasi penelitian berada dekat dengan sumber mata air panas sehingga dengan temperatur yang tinggi di bawah permukaan akan menyebabkan batuan mengalami pelapukan (Summerfield, 1991).

Dari hasil pengolahan data, setiap lapisan pada lintasan memiliki ketebalan yang berbeda, untuk menghitung ketebalan lapisan di setiap lintasan dilakukan pada software Plotrefa dan dilakukan dengan merata-ratakan ketebalannya, dikarenakan setiap lapisan pada lintasan memiliki ketebalan yang bervariasi seperti yang dihasilkan oleh penampang seismik 2-D. Berdasarkan hasil pengukuran dan pengolahan data ke 4 Lintasan, diduga setiap lapisannya merupakan lapisan lapuk dikarenakan area lokasi penelitian merupakan daerah panasbumi dengan temperatur yang tinggi sehingga menjadi faktor penyebab lapuknya suatu batuan (Summerfield, 1991).

\section{Lintasan 2 merupakan lintasan} dengan kecepatan gelombang seismik refraksi yang paling rendah, sedangkan jarak titik sumber mata air panas terletak paling jauh dari lintasan 2, dari pengolahan data yang dilakukan diduga hal ini disebabkan batuan pada lapisan ini merupakan batuan sedimen yang tidak terkonsolidasi. Lapisan dengan kecepatan gelombang seismik refraksi yang rendah memiliki porositas yang besar, semakin besar porositas suatu batuan maka akan semakin kecil nilai densitas suatu batuan tersebut sehingga menyebabkan gelombang seismik akan merambat dengan kecepatan yang lebih lambat (Sheriff dan Gildart, 1995). Berdasarkan peta geologi lokasi penelitian terdapat sesar normal yang mungkin juga menjadi penyebab lapuknya suatu lapisan.

Lintasan 2 juga diduga memiliki pori-pori batuan yang terisi fluida, sehingga akan memberikan pengaruh 
terhadap cepat rambat gelombang seismik pada formasi batuan tersebut (Sheriff dan Gildart, 1995). Hal ini dikarenakan lokasi daerah penelitian ini merupakan daerah panasbumi dimana lokasi penelitian berada pada sumber mata air panas, sehingga akan membuat batuan mudah merekah. Berbeda dengan Lintasan 1, Lintasan 3, dan Lintasan 4 dimana ke 3 lintasan ini memiliki kecepatan gelombang seismik refraksi yang tinggi dibandingkan dengan kecepatan gelombang seismik refraksi pada Lintasan 2, sedangkan jarak titik sumber mata air panas terletak paling dekat dengan Lintasan 1, Lintasan 3, dan Lintasan 4.

Dari proses pengolahan data yang dilakukan di Lintasan 1, Lintasan 3, dan Lintasan 4, formasi batuan ke 3 lintasan ini memiliki kecepatan gelombang seismik yang lebih besar sehingga porositas batuan pada lintasan ini lebih kecil, maka akan membuat batuan lebih sedikit menyimpan fluida pada pori-pori batuan dan akan lebih sulit untuk membuat batuan merekah (Sheriff dan Gildart, 1995). Penentuan struktur batuan bawah permukaan pada semua lintasan ditentukan dengan melihat kecepatan penjalaran gelombang seismik di bawah permukaan, kemudian nilai kecepatan penjalaran gelombang seismik tersebut diklasifikasikan dengan kecepatan gelombang $\mathrm{P}$ pada berbagai batuan sedimen yang terdapat pada Tabel 2, sehingga perlapisan bawah permukaan pada semua lintasan, struktur batuan penyusunnya dapat diketahui. Selanjutnya nilai kecepatan penjalaran gelombang seismik dalam rangeyang sama, tetapi penentuan struktur batuannya berbeda, ini ditentukan dengan melihat kondisi geologi wilayah penelitian. Kondisi geologi wilayah penelitian ini terdiri atas formasi Latimojong, Batuan Gunung Api Tineba, Granit Kambuno serta endapan danau berupa lempung, yang memiliki deskripsi batuan yang berbeda pada tiap formasi batuan tersebut.

Tabel 2 Kecepatan gelombang P pada berbagai batuan sediment

\begin{tabular}{|l|c|}
\hline \multicolumn{1}{|c|}{ BATUAN } & $\begin{array}{c}\text { KECEPATAN } \\
\mathrm{Vp}(\mathrm{m} / \mathrm{s})\end{array}$ \\
\hline Lapuk berlapis & $300-900$ \\
Tanah & $250-600$ \\
Alluvium & $500-2.000$ \\
Tanah liat & $1.000-2.500$ \\
Pasir tak tersaturasi & $200-1.000$ \\
Pasir tersaturasi & $800-2.200$ \\
Pasir dan kerikil tak & $400-500$ \\
tersaturasi & \\
Pasir dan kerikil & $500-1.500$ \\
tersaturasi & \\
Granit & $5.000-6.000$ \\
Basal metemorf & $5.400-6.400$ \\
Batuan min & $3.500-7.000$ \\
Batu pasir dan serpih & $2.000-4.500$ \\
Batu kapur & $2.000-6.000$ \\
\hline
\end{tabular}

Sumber: (Burger, 1992).

Hasil analisis nilai ketebalan dan kecepatan gelombang seismik pada daerah penelitian ini menunjukkan perbedaan pada setiap lintasannya, hal ini disebabkan formasi batuan pada setiap lintasan 
memiliki kecepatan gelombang seismik refraksi yang berbeda dan lokasi penelitian merupakan area panasbumi dimana area panasbumi memiliki lapisan bawah permukaan yang lapuk yang disebabkan oleh faktor temperatur yang tinggi di bawah permukaannya.

\section{DAFTAR PUSTAKA}

Burger, H. R. (1992). Exploration geophysics of the Shallow Subsurface.Prentice Hall. P T R.

Rosid, S., dan Setiawan, B. (2008). Pemetaan tingkat kekerasan batuan menggunakan metode seismik refraksi. Prosiding SeminarNasional Sains dan Teknologi-II 2008. Lampung. Universitas Lampung.

Santoso, D. (2004).Eksplorasi Energi Geothermal. Bandung. Penerbit ITB.

Sheriff dan Gildart.(1995). Exploration Seismology. United States Of America. Cambridge University Press.

Simanjuntak, T., O, Suruno., dan Supandjono, J.B. (1997). Peta Geologi Lembar Poso. Sulawesi.

Sismanto.(1999). Eksplorasi Dengan Menggunakan Sesimik Refraksi. UGM. Yogyakarta.

Summerfield, M.A. (1991). Global GheomorphologyAn Introduction to the study of Landform. Longman Singapore Pub. Singapore. 